\title{
Contemporary extinctions and population declines of the monarchs (Pomarea spp.) in French Polynesia, South Pacific
}

\author{
Jean-Claude Thibault and Jean-Yves Meyer
}

\begin{abstract}
Four species of monarchs (Pomarea spp.) presently inhabit French Polynesia, one on Tahiti and three on the Marquesas Islands. Although all species populations were abundant during the nineteenth century or at the beginning of the twentieth century, their range and population numbers have recently decreased dramatically: intensive field surveys conducted between 1998 and 2000 reveal that four subspecies are now
\end{abstract}

extinct from five islands in the Marquesas in the last decades. Introduction of the black rat is the major cause of extinction and decline, now amplified by new threats such as aggressive introduced birds and invasive alien plants reducing suitable habitats for breeding.

Keywords Extinction, monarch, Polynesia, Pomarea, threats.

\section{Introduction}

Impoverishment of the native avifauna in the Pacific Islands by human actions began long ago (Steadman, 1995), and it has continued until the present, with the extinction of several endemic forms and a drastic restriction in their range (Collar et al., 1994). Monarchs of the genus Pomarea (Aves) constitute a good example of the erosion of terrestrial biodiversity in island ecosystems. They are currently restricted to eastern Polynesia (South Pacific) with one species on Rarotonga (Cook Islands), one on Tahiti (Society Islands) and three on the Marquesas Islands. One more extinct form (Pomarea pomarea) from Maupiti (Society Islands) is only known from a painting (dated 1828) (Duperrey, 18251830; see also Holyoak \& Thibault, 1984). It is possible that unrecorded taxa have vanished from several other high islands in south-eastern Polynesia. This would explain their present patchy distribution (Fig. 1). These five surviving species are highly threatened (Collar et al., 1994), some by direct and active threats, such as introduced species (Robertson et al., 1994; J.-C. Thibault, J.-L. Martin, A. Penloup \& J.-Y. Meyer, unpublished data), others because they are restricted to only one small-sized island where the availability of suitable habitat has decreased (Table 1). The aim of this paper is to describe the current status, range and estimated number of monarchs from French Polynesia, on Tahiti and the Marquesas Islands.

\footnotetext{
Jean Claude Thibault (corresponding author) Parc nautrel régional de Corse, B.P. 417, rue Major Lambroschini, F-20184 Ajaccio, Corsica. E-mail: JnCldTHIBAULT@aol.com

Jean-Yves Meyer Delegation a la Recherche, B.P. 20981, Papeete, Tahiti, French Polynesia

Revised manuscript accepted for publication 22 September 2000
}

The islands where the species are located have been visited at least twice between the 1970s and 2000. Their characteristics, including their estimated range of suitable habitat, are indicated in Table 1. In fact, all islands of the Marquesas which might potentially have populations of Pomarea spp. were surveyed. For description of the vegetation types we have followed Florence \& Lorence (1997). Sometimes, we refer to birds in 'immature plumage', because in all Pomarea species the immature birds are easily recognizable from their colouration, i.e. brown, cinnamon-buff, rufous or orange, according to the species (Murphy \& Mathews, 1928; Pratt et al., 1987). Adult plumage is obtained progressively, for example it does not develop fully until the fourth year in the Rarotonga monarch (Robertson et al., 1993), the only species where this phenomenon has been studied. The mean density of the three species from the Marquesas Islands was obtained by mapping territories occupied by pairs of adults whose ranges were estimated using standardized methods.

\section{Species accounts and range}

\section{Tahiti monarch}

\section{Tahiti}

Pomarea nigra (Sparrman) was reported to be common by both Lesson (1839) who visited Tahiti in 1823, and Peale (1848). However, by the beginning of the twentieth century, the species was considered rare: Seale (19011902) collected only one specimen inland in 1902 (Papenoo Valley), and Wilson (1907) did not find any. From September 1920 to June 1923, the Whitney South Sea Expedition (WSSE), after intensive searches, collected 25 specimens from three localities only, ranging $65-$ $700 \mathrm{~m}$ in the small valleys of the western coast and inland (from December 1920 to May 1921; Quayle, 1920- 


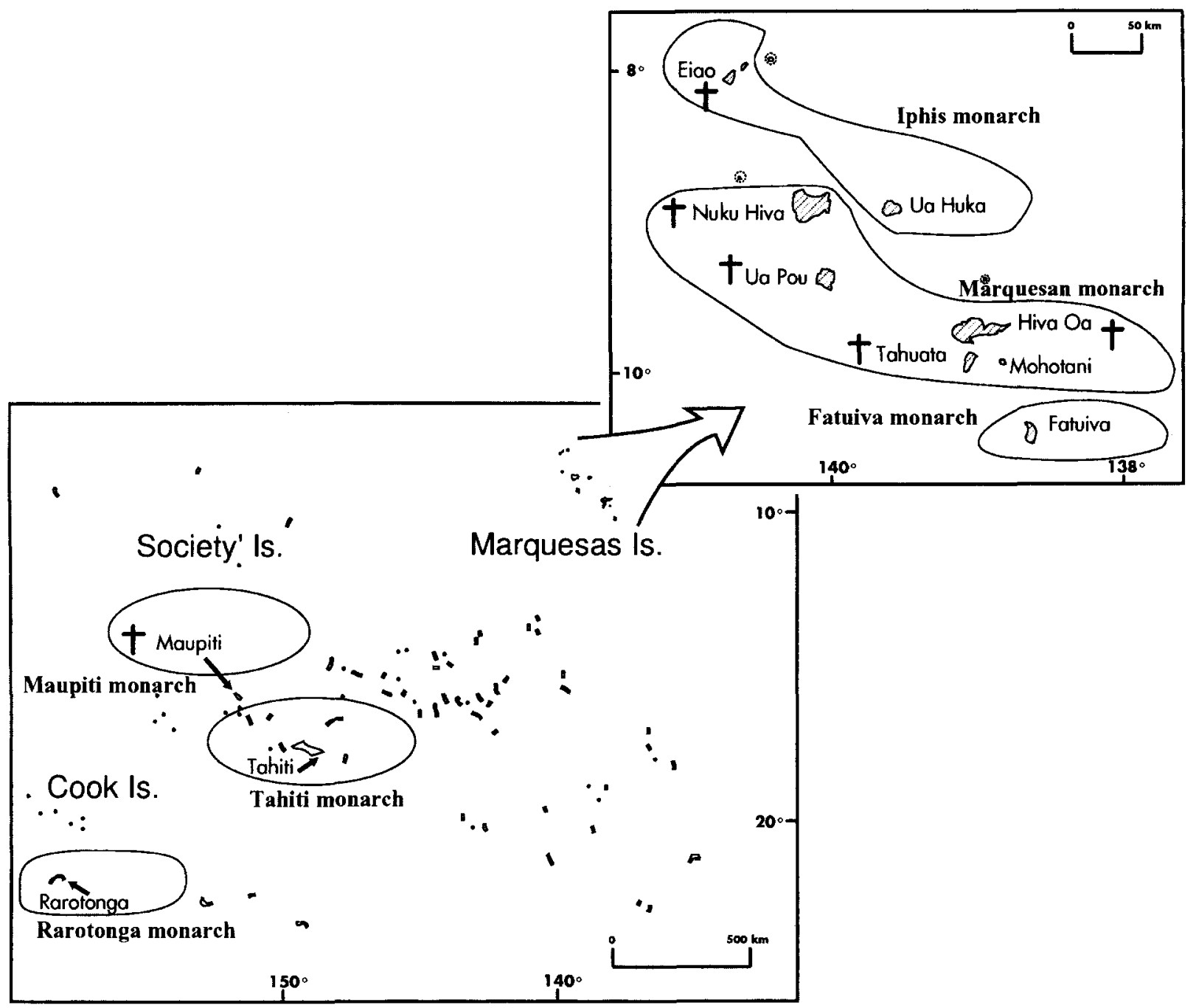

Fig. 1 Distribution of monarch species in Eastern Polynesia.

Table 1 The monarchs of French Polynesia: characteristics of islands and habitats, completed by date of last record for extinct taxa and estimate number of survival populations [data on total surface from Bonvallot (1993), except for Mohotani (Meyer, 1996); data on maximum elevation from Service de l'Urbanisme, section topographique, pers. comm.].

\begin{tabular}{|c|c|c|c|c|c|c|c|}
\hline Taxa & Island & $\begin{array}{l}\text { Latitude }(S) \text { and } \\
\text { longitude }(W)\end{array}$ & $\begin{array}{l}\text { Total } \\
\text { surface } \\
\left(\mathrm{km}^{2}\right)\end{array}$ & $\begin{array}{l}\text { Maximum } \\
\text { elevation } \\
\text { (m) }\end{array}$ & $\begin{array}{l}\text { Remnant of } \\
\text { native forest } \\
\text { (\% of total surface) }\end{array}$ & $\begin{array}{l}\text { Last record } \\
\text { for extinct } \\
\text { taxa }\end{array}$ & $\begin{array}{l}\text { Current } \\
\text { estimated number } \\
(1998-2000)\end{array}$ \\
\hline \multicolumn{8}{|l|}{ Society Islands } \\
\hline P. nigra & Tahiti & $17^{\circ} 48^{\prime} / 149^{\circ} 30^{\prime}$ & 1045 & 2241 & c. $25 \%$ & & c. 30 ind. \\
\hline P. pomarea & Maupiti & $16^{\circ} 27^{\prime} / 152^{\circ} 16^{\prime}$ & 12 & 372 & $1 \% ?$ & 1830 s? & \\
\hline \multicolumn{8}{|l|}{ Marquesas Islands } \\
\hline P. iphis fluxa & Eiao & $8^{\circ} 00^{\prime} / 140^{\circ} 42^{\prime}$ & 40 & 577 & c. $9 \%$ & 1977 & \\
\hline P.i.iphis & Ua Huka & $8^{\circ} 55^{\prime} / 139^{\circ} 33^{\prime}$ & 83 & 884 & c. $30 \%$ & & 500-1250 pairs \\
\hline \multirow[t]{2}{*}{ P. m. mendozae } & Hiva Oa & $9^{\circ} 46^{\prime} / 139^{\circ} 00^{\prime}$ & 315 & 1276 & $?$ & 1975 & \\
\hline & Tahuata & $9^{\circ} 55^{\prime} / 139^{\circ} 05^{\prime}$ & 61 & 1050 & $?$ & 1922 & \\
\hline P. m. mira & Ua Pou & $9^{\circ} 24^{\prime} / 140^{\circ} 05^{\prime}$ & 105 & 1203 & $?$ & 1985 & \\
\hline P. m. nukuhizae & Nuku Hiva & $8^{\circ} 52^{\prime} / 140^{\circ} 06^{\prime}$ & 339 & 1224 & $?$ & $1930 \mathrm{~s}$ & \\
\hline P. m. motanensis & Mohotani & $9^{\circ} 59^{\prime} / 138^{\circ} 50^{\prime}$ & 13 & 520 & $15-20 \%$ & & 80-125 pairs \\
\hline P. whitneyi & Fatuiva & $10^{\circ} 29^{\prime} / 138^{\circ} 39^{\prime}$ & 85 & 1125 & ? & & 200-500 pairs \\
\hline
\end{tabular}


1923). Records after this date are rare, but include: (i) 1937 in the Papenoo Valley (S.D. Ripley in Holyoak \& Thibault, 1984), (ii) the 1940s near Lake Vaihiria (Anon, 1998a), and (iii) 1972 above Paea (Holyoak, 1974). In 1974, a population of $20-50$ pairs was discovered at Mt Marau (north-west of Tahiti) between 750 and $950 \mathrm{~m}$ in native upper- to high-elevation wet forest dominated by the native trees Crossostylis biflora, Weinmannia parviflora and Metrosideros collina (Thibault \& Holyoak, 1977); this population was monitored until 1984 (M.K. Poulsen, unpublished data). All the later bird searches (1986: C. Monnet, pers. comm.; 1989: Seitre \& Seitre, undated; 1996-1998, pers. obs.) proved unsuccessful.

In the 1990s, field investigations were conducted in most of the valleys of Tahiti (Monnet et al., 1993; Thibault et al., 1999; Blanvillain, 2000). Results demonstrated the following: (i) birds seem to have disappeared from inland locations, especially from montane forest, (ii) present distribution is restricted to four small valleys located on the western coast, ranging $80-400 \mathrm{~m}$ in indigenous and secondary low- to mid-elevation moist and wet native forests dominated by the native tree Hibiscus tiliaceus and the giant fern Angiopteris evecta, with a few endemic fig trees Ficus prolixa var. prolixa, and the native large-leaved tree Neonauclea forsteri often used as a breeding site (pers. obs.), (iii) an apparent decrease in numbers inside this range between the 1980s and the late 1990s, and (iv) the present number is estimated to be fewer than 30 individuals (Thibault et al., 1999). The invasion of several invasive alien trees, such as Miconia calvescens and the African tulip tree Spathodea campanulata, both of which are able to form dense monotypic stands up to $1000 \mathrm{~m}$ (Meyer \& Florence, 1996), has dramatically reduced the range of suitable native habitats.

\section{Iphis monarch}

Eiao

Pomarea iphis fluxa Murphy and Mathews was discovered on this uninhabited island by the WSSE on 20 September 1922, with at least 55 individuals collected (Murphy \& Mathews, 1928; Holyoak \& Thibault, 1984). Beck (1920-1924) wrote that the species was 'common' in groves near the seashore, but absent on the inland plateau. Fisher was unable to find it during a brief visit in 1929 (Fisher \& Wetmore, 1931), nor we ourselves on 29 September 1975. However, on 7 August 1977, 'a few Marquesan Flycatchers (P. mendozae [sic])' were seen (Montgomery et al., 1980). The confusion of the names of the two species of monarchs does not lessen the value of this observation. Ten years later, one of us (J.C.T.) stayed on Eiao from 12 July to 8 August 1987 (Thibault, 1989); searches, however, proved unsuccessful in most wooded areas from sea level (groves at Vaituha on the northern side) to the inland plateau, and in Opituha canyon on the western side. The native low-elevation dry forest, mainly composed of Pisonia grandis (Decker, 1973), has drastically decreased because of overgrazing by feral sheep introduced c. 1880 (J.C.T., unpublished data), although some wooded areas remain in inaccessible parts in Vaituha and Opituha. There are also groves of the native trees Hibiscus tiliaceus and Thespesia populnea on the plateau inland. The present range (1987) of the forest remnants was estimated using satellite photographs at c. 340 ha (Anon, 1998b). We consider this monarch population to now be extinct.

\section{Ua Huka}

Pomarea iphis iphis Murphy and Mathews was discovered by the WSSE in 1922 (Murphy \& Mathews, 1928), and recorded regularly later (Holyoak \& Thibault, 1984; Seitre \& Seitre, undated). An intensive survey was conducted in most parts of the island from 30 July to 20 August 1998 (J.C.T., I. Guyot). Breeding birds were found from 30 to $650 \mathrm{~m}$ in all wooded areas (native low-to mid-elevation moist and wet forest dominated by Hibiscus tiliaceus and Cyclophyllum barbatum) of the southern part of the island (Vaipaee, Hane, Hokatu valleys), and locally in the Pisonia grandis and Sapindus saponaria lowland dry forest on the eastern coast. Some non-breeders were, however, found higher in native upper-elevation wet forest dominated by Metrosideros collina, Weinmannia parriflora and Cyathea affinis (two individuals were seen on 28 June 1997 at $840 \mathrm{~m}$ on the ridge from the highest summit of Mt. Hitikau, J.Y.M.). Today, the overall forest does not exceed c. 30 per cent of the range of the island (estimation after field searches, J.Y.M.). Mean density has been estimated at 2-5 pairs per 10 ha, according to the quality of the forest. The species is more common in river valley bottoms, with an overall breeding population of an estimated 500-1250 pairs. Their number and range remained relatively stable between 1975 (J.C.T.) and 1998. Birds with immature plumage (Plate 1), alone or in small flocks of up to five individuals, also visit dry and shrubby vegetation in lowland areas and on ridges inland. Their number is important, but presently impossible to estimate.

\section{Marquesan monarch}

\section{Nuku Hiva}

Pomarea mendozae nukuhivae Murphy and Mathews

Fairly numerous specimens now lodged in several museums were collected during the nineteenth century (Holyoak \& Thibault, 1984). In 1922, the species was 


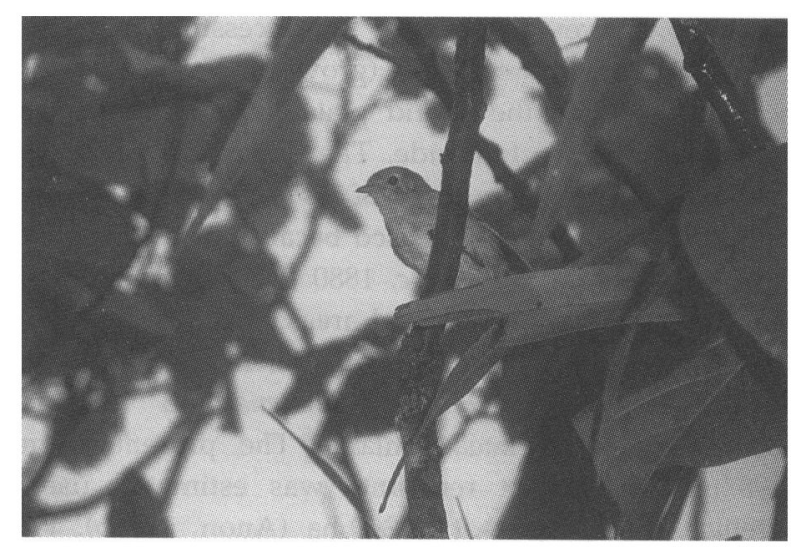

Plate 1 A juvenile Iphis monarch from Ua Huka (Jean-Yves Meyer).

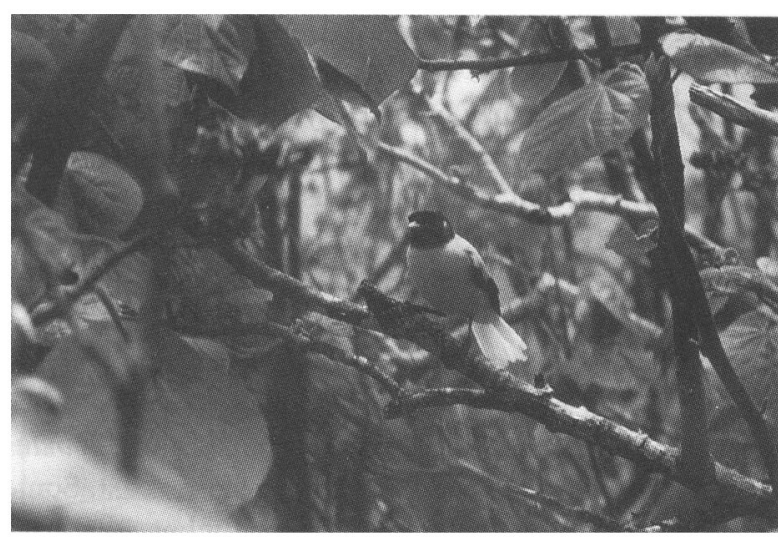

Plate 2 An adult female of Marquesan monarch from Mohotani (Jean-Yoes Meyer).

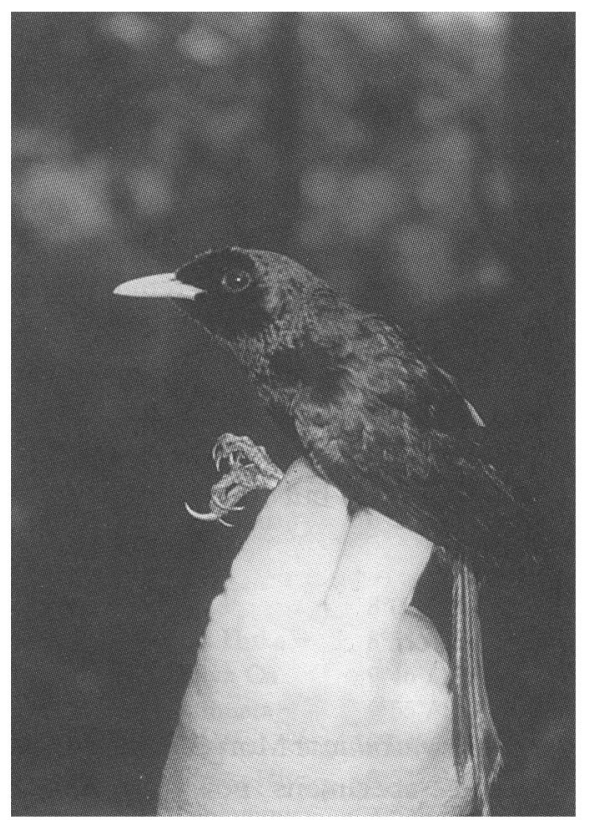

Plate 3 An adult Fatuiva monarch (Jean-Yves Meyer). not common according to the WSSE (Quayle, 19201923). Moreover, Fisher (Fisher \& Wetmore, 1931) did not see it in 1929 and unpublished notes from the 1930s confirm its rarity (unpublished written records consulted at the library of the Evêché, village of Taiohae). Pomarea mendozae nukuhivae was not recorded in 1972 (Holyoak, 1975), or in 1975 (J.C.T.) despite several weeks of intensive field searches. In July 1975, unconfirmed sightings by two hunters of a passerine bird matching the monarch's description were reported, inland, down the ridge separating Toovii plateau and the Terre déserte (c. $850 \mathrm{~m}$ a.s.l.) (Kuku, pers. comm.). However, the species was not recorded in the 1990s (i) when the range of the Marquesan imperial-pigeon Ducula galeata was mapped (A. Varney in 1993, pers. comm.; J. Evva in 1998, pers. comm.), or (ii) during botanical surveys of the Tovii plateau and ridges between 800 and $1200 \mathrm{~m}$ in 1997 and 1999 (J.Y.M.). A large proportion of the area has been overgrazed and colonized by Leucaena leucophala, a small-leaved legume tree, which is an unsuitable breeding habitat for monarchs in French Polynesia. This small tree, introduced during the first half of the twentieth century, is now widespread at low- and mid-elevations (MuellerDombois \& Fosberg, 1998). We consider this monarch population to now be extinct.

\section{Ua Pou}

Pomarea mendozae mira Murphy and Mathews

The WSSE collected at least 26 specimens on lower and inner parts of the island in 1921 and 1922 (Quayle, 19201923; Murphy \& Mathews, 1928). In 1971 and 1975, its range was restricted up to $450 \mathrm{~m}$ with an estimated number of 150-200 pairs (Holyoak \& Thibault, 1984). Five to seven pairs, with a continuous range from 450 to $730 \mathrm{~m}$, were recorded on several occasions in $1975 \mathrm{in}$ the upper Hohoi Valley, a region dominated by the native trees Hibiscus tiliaceus, Fagraea berteroana, and in drier areas, Pandanus tectorius (J.C.T.). The last record was dated March 1985, when two birds in immature plumage were observed in Hakahetau Valley (M.K. Poulsen, unpublished data).

Field searches conducted in November 1989 and January 1990 (Seitre \& Seitre, undated), then in February 1990, concentrating on the bottom of the Hohoi Valley (V. Bretagnolle, unpublished data) were unsuccessful. More recent intensive searches in several suitable forested areas in native mid- to upper-elevation moist and wet forest, between 16-30 July 1998 [Hakahau, Hakahetau, Hohoi, Paumea (J.C.T., I. Guyot)], and between 2-9 May 1999 [Hakahau Valley up to Poutetainui peak; (Anon, 1999a)], were also unsuccessful. The range of suitable habitat is now restricted solely to the montane forest, following the massive invasion of 
Leucaena leucocephala in the lowlands. We consider this monarch population to now be extinct.

\section{Hiva $\mathrm{Oa}$}

Pomarea mendozae mendozae Hartlaub from Hiva Oa and Tahuata

This bird was found to be common on Hiva Oa in 1921 and 1922 when the WSSE collected a large series of specimens (Murphy \& Mathews, 1928). In March 1975, only one individual was observed in a small valley of O'otua plateau at $c .750 \mathrm{~m}$ in native upper-elevation wet forest, despite several weekly field searches (J.C.T.). The species was not sighted-either by Seitre \& Seitre (undated) in January 1990 (Atuona Valley, Puamau Valley) or during a botanical survey conducted on $\mathrm{Mt}$ Ootua between 800 and $900 \mathrm{~m}$ in 1996 (J.Y.M.). Individuals were not located over a period of several days in February 2000, when play-back vocalizations of P. $m$. motanensis were set up at 15 stations both in the Atuona Valley (mainly Hibiscus tiliaceus groves) and on the ridges of Mt Temetiu up to $1000 \mathrm{~m}$ (see Meyer, 1996; Florence \& Lorence, 1997; for description of the vegetation types). After reading the original data (H.P. Brokaw, unpublished data), we rejected two records of single birds obtained at Atuona and Puamau (Anon, 1999), erroneously attributed to this species. We consider this monarch population to now be extinct.

Pomarea mendozae mendozae was also apparently common in 1922 on Tahuata, when the WSSE collected several specimens (Murphy \& Mathews, 1928). However, the field searches we conducted in May and June 1975 both in the lowlands and the uplands were unsuccessful (J.C.T.), as were those of Seitre \& Seitre (undated) in January 1990. We consider this monarch population to now be extinct.

\section{Mohotani or Motane}

Pomarea mendozae motanensis Murphy and Mathews (Plate 2) was first discovered on this uninhabited island by the WSSE in 1922 (Murphy \& Mathews, 1928). During four visits in 1975 about 250-350 pairs were estimated, breeding in all forested areas (Holyoak \& Thibault, 1984), from 140 to $c .500 \mathrm{~m}$ near the summit of the island, especially in the native low- to mid-elevation dry and moist forest dominated by the native trees Pisonia grandis, Cordia subcordata and Thespesia populnea (Sachet et al., 1975; Meyer, 1996).

From 7 to 9 February 2000, the birds' density was found to be stable (4-5 pairs per 10 ha estimated in the Pisonia forest); the range of suitable habitat does not seem to have changed significantly, despite overgrazing and lack of vegetation regeneration that have occurred following the introduction of a flock of sheep during the second half of the nineteenth century. The range of the remnant Pisonia forest, located in the middle of the island, is c. 200 ha according to the most recent aerial photograph (1982, Service de l'Urbanisme, Papeete). Some pairs were also found in Sapindus saponaria and Hibiscus tiliaceus groves near the inland deforested plateau on a surface of less than 50 ha. Recent estimates of breeding population numbers were only $80-125$ pairs, which differs from previous estimates because of (i) a discrepancy in the estimates of total surface area of the island between the $1970 \mathrm{~s}$ (16 sq $\mathrm{km}$ according to Decker, 1973) and today (13 sq km according to Meyer, 1996), and (ii) a more accurate estimate of forest range, based on recent aerial photographs. Immature birds were common in the shrubby vegetation dominated by the native Eugenia rariflora (reinwardtiana) and Cordia lutea. Their number is relatively important, but impossible to estimate.

\section{Fatuiva monarch}

Fatuiva or Fatu Hiva

Pomarea whitneyi Murphy and Mathews (Plate 3) was described as common when discovered by the WSSE in 1922 (Murphy \& Mathews, 1928). The population has been regularly checked since the 1970s (Holyoak \& Thibault, 1984)

Between 13 and 29 February 2000, we conducted a field survey in the valleys surrounding the Omoa village; the species was mainly present in the main valley and in the small ravines with dense and wooded native vegetation (dominated by Hibiscus tiliaceus in the valley bottom, Pandanus tectorius, Metrosideros collina on the hillsides), from 50 to $700 \mathrm{~m}$; some non-breeding birds were also found up to $775 \mathrm{~m}$, on a crest below the highest summit of $\mathrm{Mt}$ Touaouoho, in native mid- to upper-elevation wet forest dominated by Metrosideros collina and Weinmannia parviflora. Some pairs may be found in close proximity (only $100 \mathrm{~m}$ apart), but mean density calculated in lower Omoa Valley was one pair per 10 ha (eight territories mapped over a range of $75 \mathrm{ha}$ ). Similar densities have been noted in native Weinmannia parviflora-Crossostylis biflora mid-elevation wet forest on the ridges between Omoa and Hanavave valleys at $600-700 \mathrm{~m}$. We believe that the species may be present at equal densities over the rest of the island (Hanavave Valley, and small forested valleys in the south and the east), but we were unable to confirm this. A few hundred pairs have been estimated, although the lack of detailed maps showing the entire watercourse make a more accurate estimation impossible. Unlike in 1975, no birds were observed in groves of mango trees Mangifera indica on the slopes and ridges up to Omoa Valley. We are not sure whether this reflects a decrease in the range or a decline of the number of non-breeders 
Table 2 Conservation status (according to Collar et al., 1994), and main causes of extinction and current threats to the monarchs in French Polynesia.

\begin{tabular}{|c|c|c|c|}
\hline Species name & Conservation status & Sub-species name & Causes of extinction or decline \\
\hline \multicolumn{4}{|l|}{ Society Islands } \\
\hline P. nigra & CR & & Black rat, introduced birds, invasive plants \\
\hline P. pomarea & EX & & $\uparrow$, unknown (black rat, intense secondarization of the vegetation?) \\
\hline \multicolumn{4}{|c|}{ Marquesas Islands } \\
\hline P. iphis & VU & $\begin{array}{l}\text { P. i. fluxa } \\
\text { P. i. iphis }\end{array}$ & $\begin{array}{l}\dagger \text {, unknown (black rat, overgrazing by feral sheep or disease?) } \\
\text { decrease of forest by overgrazing }\end{array}$ \\
\hline P. mendozae & $\mathrm{EN}$ & $\begin{array}{l}\text { P. m. mendozae } \\
\text { P.m. nukuhivensis } \\
\text { P.m.mira } \\
\text { P. m. motanensis }\end{array}$ & $\begin{array}{l}\dagger, \text { black rat, decrease of native forest (invasive plants)? } \\
\dagger, \text { black rat, decrease of native forest (invasive plants, cattle)? } \\
\dagger, \text { black rat, decrease of native forest (invasive plants)? } \\
\text { Overgrazing by feral sheep }\end{array}$ \\
\hline P. whitneyi & VU & & Black rat, decrease of native forest (fire, goats) \\
\hline
\end{tabular}

$\mathrm{CR}$ - critical, EX - extinct, VU - vulnerable, EN - endangered, $\uparrow$ - extinct form.

outside territories occupied by adults. Both the lack of adults accompanied by immature birds and the small number of non-breeders in immature plumage seen outside the range of adult populations, suggest a low breeding success. This is probably linked to the recent arrival of the black rat (Rattus rattus) (Thibault \& Meyer, 2000).

\section{Implications for conservation}

The current situation concerning the four endemic monarch species from Tahiti (Society Islands) and the Marquesas Islands is dramatic and their conservation status is alarming. Firstly, they have apparently been extirpated in the last decades from five islands in the Marquesas Islands (Eiao, Nuku Hiva, Ua Pou, Hiva Oa and Tahuata) where they were represented by four endemic subspecies. Secondly, two species ( $P$. nigra and $P$. mendozae) represented locally by large population numbers during the nineteenth century (as on Tahiti) or at the beginning of the twentieth century (as on Nuku Hiva) are scarce today. Even on Ua Huka and Fatuiva, monarch populations - although present today in fairly high density - have strongly declined as a result of the reduction of forested areas (by overgrazing of feral sheep, cattle, horses and goats). The main causes of extinction and population decline are summarized in Table 2. The introduction of the black rat is certainly one of the major causes of extinction or decline (Seitre \& Seitre, 1992; Robertson et al., 1994). The problem has been exacerbated by new threats such as the introduction of aggressive birds (e.g. the red-vented bulbul Pycnonotus cafer, recently introduced to Tahiti in the 1970 s which has subsequently spread across the whole island) and invasive alien plants, which cause the reduction of suitable habitats for breeding (J.-C. Thiba- ult, J.-L. Martin, A. Penloup \& J.-Y. Meyer, unpublished data).

Several conservation projects are being conducted in French Polynesia to prevent the total extinction of these species: a rat-control programme has been in progress for the recovery of the Tahiti monarch since 1998 (by the Society of Ornithology of French Polynesia), and another is planned for the Fatuiva monarch; the building of a fence on Mohotani to protect the forest against sheep damage was proposed to the Service du Développement Rural (the Department of Agriculture of French Polynesia) and the Délégation à l'Environnement (the Department of the Environment). Finally, it is recommended that boxes with bait, which should be renewed on a regular basis, be placed on the wharf of Ua Huka to prevent the spread of the black rat.

Conservation of this endemic genus, of which all members are threatened, constitutes a real challenge. However, control of the black rat (Robertson et al., 1994) lead to a marked increase in numbers of the Rarotonga monarch in the Cook's Islands, which offers encouragement for other projects.

This paper focuses on the status and impact of various threats on the remnant monarch populations. Future publications will address detailed conservation recommendations, drawing on empirical data and additional fieldwork.

\section{Acknowledgements}

This work was carried out for the Société d'Ornithologie de Polynésie (contract from the Fonds d'Investissement et de Développement Economique et Social from the government of French Polynesia). We express our gratitude to Vincent Bretagnolle, Caroline Blanvillain*, Howard Brokaw, Jolt Evva, Peter Gaze, Isabelle Guyot, Didier 
Lequeu, Jean-Pierre Luce, the late Claude Monnet*, M.K. Poulsen, Philippe Raust*, Teiki Richmond, Jean-Marc Salducci*, Georges Sandford*, Robert Sulpice, and Albert Varney* (*members of the S.O.P.) for facilities or original data; to the American Museum of Natural History, especially François Vuilleumier and Mary LeCroy for facilities to examine the collection and for access to the WSSE material; and to the Centre de Recherches Insulaires et Observatoire de l'Environnement (Moorea, French Polynesia), especially Bernard Salvat, for facilities in the Marquesas Islands during our one-year stay in 1975 (J.C.T.). Elena Bulmer has improved the English. Thanks are also due to G. Dutson and an anonymous referee for the helpful remarks concerning the manuscript. Special thanks is given to Leon Lichtle, the mayor of Ua Huka, for facilities provided to J.Y.M. in 1996 and 1997 and to J.C.T. in 1998, and for his efforts to promote conservation of native species and natural areas in his island.

\section{References}

Anon (1998a) Observations ornithologiques. Te Manu (Tahiti), 23, 1.

Anon (1998b) Cartographie sommaire de la végetation par images SPOT des iles et atolls de Bellinghausen, Scilly, Mopelia, Taiaro, Eiao, Hatutaa et Motu One. SNC Pae Tai-Pae Uta/Station Polynésienne de Télédétection, IFREMER. Unpublished report for the Délégation à l'Environnement, Papeete.

Anon (1999a) Observations ornithologiques. Te Manu (Tahiti), 27, 1-2.

Anon (1999b) Observations ornithologiques. Te Manu (Tahiti), 29, 1-2.

Beck, R.H. (1920-1924) Unpublished Journal of the Whitney South Sea Expedition. Vol. E. American Museum of Natural History, New York.

Bonvallot, J. (1993) La géomorphologie. In Atlas de la Polynésie Française, pp. 34-37. Editions de l'ORSTOM (Institut français de recherche scientifique pour le développement en coopération), Paris.

Blanvillain, C. (2000) Programme de sauvegarde du monarque de Tahiti: des premiers résultats prometteurs pour la survie de l'espèce. Te Manu (Tahiti), 30, 3-4.

Collar, N.J., Crosby, M.J. \& Stattersfield, A.J. (1994) Birds to Watch 2. The World List of Threatened Birds. Bird Life International, Cambridge.

Decker, B.G. (1973) Unique dry-island biota under official protection in northwestern Marquesas Islands (Iles Marquises). Biological Conservation, 5, 66-67.

Duperrey, L.I. (1825-1830) Voyage autour du Monde... la corvette... La Coquille... 1822, 1823, 1824 et 1825.7 vols. Arthus Bertrand, Paris.

Fisher, A.K. \& Wetmore, A. (1931) Report on birds recorded by the Pinchot Expedition of 1929 to the Caribbean and Pacific. Proceedings of the US Natural History Museum, 79, 1-66.

Florence, J. \& Lorence, D.H. (1997) Introduction to the flora and the vegetation of the Marquesas Islands. Allertonia, $7,226-237$.
Holyoak, D.T. (1974) Les oiseaux des îles de la Société. Oiseau \& Revue française d'Ornithologie, 44 (1-27), 153-184.

Holyoak, D.T. (1975) Les oiseaux des îles Marquises. Oiseau $\mathcal{E}$ Reoue française d'Ornithologie, 45, 207-234.

Holyoak, D.T. \& Thibault, J.-C. (1984) Contribution à l'étude des oiseaux de Polynésie orientale. Mémoires du Muséum national d'Histoire naturelle, Paris, 127, 1-209.

Lesson, P. (1839) Voyage Autour du Monde Entrepris par Ordre du Gouvernement sur la Corvette la Coquille. P. Pourrat, Paris.

Meyer, J.-Y. (1996) Espèces et espaces menacés de la Société et des Marquises. Contribution à la Biodiversité de la Polynésie Française no.1-5. Délégation à l'Environnement/Délégation à la Recherche, Papeete.

Meyer, J.-Y. \& Florence, J. (1996) Tahiti's native flora endangered by the invasion of Miconia calvescens DC (Melastomatacae). Journal of Biogeography, 23, 775-781.

Monnet, C., Thibault, J.-C. \& Varney, A. (1993) Stability and changes during the twentieth century in the breeding landbirds of Tahiti (Polynesia). Bird Conservation International, 3, 261-280.

Montgomery, S.L., Gagné, W.C. \& Gagné, B.H. (1980) Notes on birdlife and nature conservation in the Marquesas and Society Islands. Elepaio, 40, 152-155.

Mueller-Dombois, D. \& Fosberg, F.R. (1998) Vegetation of the Tropical Pacific Islands. Springer-Verlag, New York.

Murphy, R.C. \& Mathews, G.M. (1928) Birds collected during the Whitney South Sea Expedition. V. American Museum Novitates, 337, 1-9.

Peale, T.R. (1848) US Exploring Expedition during the years $1838-1842$, etc. Mammalogy and Ornithology, vol. 8 . Philadelphia.

Pratt, H.D., Bruner, P.I. \& Berrett, D.G. (1987) A Field Guide to the Birds of Hawaii and the Tropical Pacific. Princeton University Press, Princeton.

Quayle, E.H. (1920-23) Unpublished Journal of the Whitney South Sea Expedition, Vol. G-I. American Museum of Natural History, New York.

Robertson, H.A., Hay, J.R. \& Saul, E.K. (1993) Age and sex determination of Kakerori Pomarea dimidiata. Notornis, 40, 179-187.

Robertson, H.A., Hay, J.R., Saul, E.K. \& McCormack, G.V. (1994) Recovery of the Kakerori: an endangered forest bird of the Cook Islands. Conservation Biology, 8, 1078-1086.

Sachet, M.-H., Schafer, P.A. \& Thibault, J.-C. (1975) Mohotani, une île protégée aux Marquises. Bulletin Société études Océaniennes, Papeete, 16, 557-568.

Seale, A. (1901-1902) Expedition to South-Eastern Polynesia (Unpublished Journal). Bernice P. Bishop Museum, Honolulu.

Seitre, R. \& Seitre, J. (undated) Causes de Disparition Des Oiseaux Terrestres de Polynésie Française. SPREP Occasionnal Paper Series no. 8. CRS, Nouméa.

Seitre, R. \& Seitre, J. (1992) Causes of land-bird extinctions in French Polynesia. Oryx, 26, 215-222.

Steadman, D.W. (1995) Prehistoric extinctions of Pacific Island birds: biodiversity meets zooarchaeology. Science, 267, 11231131.

Thibault, J.-C. (1989) L'avifaune des îles Eiao et Hatuta'a (Polynésie, Pacifique sud): modifications intervenues au ème siècle. Oiseaux $\mathcal{E}$ Revue française d'Ornithologie, 59, 305324. 
Thibault, J.-C., Blanvillain, C. \& Monnet, C. (1999) Plan de conservation du 'omama'o (Monarque de Tahiti Pomarea nigra). Etudes des mécanismes de raréfaction. Unpublished report. Société d'ornithologie de Polynésie, Papeete, Tahiti.

Thibault, J.-C. \& Holyoak, D.T. (1977) L'avifaune du Mont Marau, Tahiti. Bulletin Société Études Océaniennes, 16, 700-705.

Thibault, J.-C. \& Meyer, J.-Y. (2000) L'arrivée du rat noir (Rattus rattus) à Fatuiva (îles Marquises). Te Manu (Tahiti), 31, 5-7.

Wilson, S.B. (1907) Notes on birds of Tahiti and the Society Group. Ibis (9th Sér.), 3, 373-379.

\section{Biographical sketches}

Dr Jean-Claude Thibault is scientific assistant at the Parc naturel régional de Corse. Working in the Mediterranean Islands and Polynesia, he is mainly interested by changes in range and number in relation to human interactions for both seabirds and endemic land birds.

Dr Jean-Yves Meyer is a plant ecologist and field botanist working for the Délégation à la Recherche, a governmental agency. He is currently working on a recovery programme for rare, endemic plants endangered by the invasive plant Miconia calvescens on Tahiti and Moorea, and conducting ecological surveys in natural areas of high conservation value in the Marquesas and the Austral Islands. 